\title{
A Comparative Life Cycle Assessment (LCA) of Gasoline Blending with Different Oxygenates in India
}

\author{
Sushil M. Chaudhari* and Rohit B. Meshram**† \\ *Institute of Chemical Technology, Matunga, Mumbai-400019, India \\ **CSIR National Metallurgical Laboratory, Jamshedpur-831007, India \\ $\dagger$ Corresponding author: Rohit B. Meshram; rohitmeshramiit@gmail.com
}

\author{
Nat. Env. \& Poll. Tech. \\ Website: www.neptjournal.com \\ Received: 16-02-2021 \\ Revised: 20-04-2021 \\ Accepted: 25-05-2021 \\ Key Words: \\ Gasoline \\ Methanol \\ Ethanol \\ n-butanol \\ Life cycle assessment
}

\begin{abstract}
This paper includes a cradle-to-gate life cycle impact evaluation of gasoline blends in India. The potential environmental impacts of gasoline blends with three major components, i.e., methanol, ethanol, and $\mathrm{n}$-butanol are assessed. The production of methanol from the natural gas reforming process, ethanol from hydrogenation with nitric acid, and n-butanol from the oxo process are considered in the current study. The results show that the gasoline blending with methanol has the lowest impact (11 categories) and is nearly constant from 5 to $15 \%$. For gasoline with ethanol as an additive, the global warming potential, ozone depletion potential, and abiotic depletion potential rise with increasing ethanol addition. Meanwhile, increasing ethanol addition reduces the acidification potential and terrestric ecotoxicity potential impact of gasoline blends. Similarly, gasoline with $n$-butanol as an additive has higher acidification potential, eutrophication potential, human toxicity potential, terrestric ecotoxicity potential, marine aquatic ecotoxicity potential, and photochemical ozone creation potential compared to methanol and ethanol.
\end{abstract}

\section{INTRODUCTION}

India's energy security has become a critical issue with major concerns about oil and other fossil fuel depletion, environmental issues (in particular climate change), reliance on foreign sources, etc. Pollution is a major contributor to climate change. Many national and international policymakers are making reforms continuously to curtail pollution. Alcohol usage as an oxygenate fuel has the potential to reduce current emissions pollution occurring due to the properties of gasoline and its content (Yusri et al. 2017, Surisetty et al. 2011). Mainly, methanol $\left(\mathrm{CH}_{3} \mathrm{OH}\right)$, ethanol $\left(\mathrm{C}_{2} \mathrm{H}_{5} \mathrm{OH}\right)$, n-butanol $\left(\mathrm{C}_{4} \mathrm{H}_{9} \mathrm{OH}\right)$, and dimethyl ether $\left(\mathrm{C}_{2} \mathrm{H}_{6} \mathrm{O}\right)$ were commonly used as potential fuels (Yusri et al. 2017).

However, alcohol is a clean-burning fuel that has been blended into gasoline since 1980 (Chen et al. 2018). Because of its higher octane rating and high intramolecular oxygen concentration, it can be used as a fuel in machines that have a greater compression ratio and higher thermal efficiency. However, due to the hydrophilic property of alcohol, it leads to phase separation, which is a major difficulty in alcohol blended fuels, causing operational problems and engine damage. Different blending agents have been reported by researchers to avoid methanol-gasoline phase separation (Karaosmanoglu et al. 2000). It has proven scientific records for methanol to blends of M5 to M100 (Sheehy et al. 2010,
Yuen et al. 2010) and ethanol to blends of E5, E10, and E85 (Shirvani et al. 2020) where M and E represent the percentage of methanol and ethanol in the blend and remaining is gasoline.

Multiple researchers have reported that the blending of alcohol with gasoline can minimize air pollution. Alcohol emits lesser pollutants such as nitrogen oxides (NOx), SOx, and particulate matter compared to gasoline (Canakci et al. 2013, Yanju et al. 2008).

The environmental impact of any fuel was observed in two conditions, one is during production and the second during vehicular emission or combustion. In India, similar to China, the majority of coal to methanol process is feasible due to the abundance of coal (Saraswat \& Bansal 2017). Hence, the scientific community and government authorities considered oxidative additives as oxygen for the energy sector, with the goal of reducing foreign dependency in the future. Out of multiple oxygenates, methanol and ethanol prove low-cost sustainable options for gasoline blending (Shirvani et al. 2020, Saraswat \& Bansal 2017).

There are mainly two sources reported for the production of methanol, i.e., natural gas, and coal. Natural gas (NG) to methanol emits much carbon dioxide per unit of energy used as gasoline. Whereas, methanol produced from coal produces double carbon dioxide, even if emission remains 
the same. Butanol has better fuel properties as compared to ethanol such as higher heating value, lower vapor pressure, lower heat of vaporization, etc. That is why butanol can be used $100 \%$ as fuel in a spark-ignition (SI) engine. The only major issue is that biological and chemical pathways to butanol synthesis are both expensive (Ndaba et al. 2015, Popuri \& Bata 1993). Henceforth, it is necessary to understand how to oxygenate blended gasoline and its production route may impact the transportation network, storage, and environmental impacts, among other things (Chen et al. 2018, Karaosmanoglu et al. 2000).

In India, according to Economics Times, the Government transport ministry is looking to push legislation to increase the ethanol and methanol blending in gasoline to reduce the import of fossil-based gasoline. As per Indian Government policy, the Indian Oil Corporation produces a $10 \%$ ethanol and $15 \%$ methanol (depends on availability) blend. Methanol production costs are less than half of what ethanol costs to produce, which is meant to be blended at $10 \%$, but producers are struggling to supply sufficient ethanol to meet the mandate.

Life cycle assessment (LCA) of gasoline and diesel blending options is a well-defined track for crude oil (Mata et al. 2003). Many researchers studied the life cycle assessment of methanol, ethanol, and butanol blended with gasoline and compared environmental impacts and leak emissions only during transportation. However, depending on the type of engine, the research octane number and Reid vapor pressure after blending with gasoline have limitations. Most of the emissions comparison has been shown with different methanol blends. The research on gasoline blending, different additives, and its development technology has high growth in India. However, very few authors have studied the gasoline blending production impacts. It has been noticed that no literature is accessible on the comprehensive LCA of gasoline blending in India. The objective of the present investigation is to examine cradle-to-gate ecological implications of gasoline blending with different oxygenates, namely, (a) methanol, (b) ethanol, and (c) n-butanol in India during the year 2020-2021.

\section{MATERIALS AND METHODS}

\section{Alcohol Production}

\section{Methanol production}

Despite the growing demand for methanol as a transportation fuel component and an alternative fuel in India, conventional processes are still dominant. The most common route for the production of methanol is via syngas, although there are numerous available sources of feedstock for syngas production. The traditional route for methanol production could be summarized as:

Carbon Source + oxygen (or air) $\rightarrow$ Syngas $(\mathrm{CO}+$ hydrogen $)$ $\rightarrow$ methanol

Syngas production can be prepared using several methods such as steam reforming of natural gas or naphtha (Heo et al. 2020), partial oxidation of natural gas and other hydrocarbons (Ma et al. 2019), auto thermal reforming (Hu et al. 2020), gasification technologies (Ramalingam et al. 2020), etc. India's present focus is on producing methanol via syngas from low-grade coal and solid waste (fossil or biomass) that would otherwise be burned or incinerated, as well as by-products of other sectors such as steel factories, cement plants, and refineries.

$$
\begin{gathered}
\mathrm{CH}_{4}+\mathrm{H}_{2} \mathrm{O} \leftrightarrow \mathrm{CO}+3 \mathrm{H}_{2} \\
\mathrm{CO}+2 \mathrm{H}_{2} \rightarrow \mathrm{CH}_{3} \mathrm{OH}
\end{gathered}
$$

The chemical reactions carried out in the production of methanol are mentioned in Eq. 1 and Eq. 2. Whereas, Eq. (1) and Eq. (2) the overall reaction is endothermal at reactor pressure 5- $30 \mathrm{MPa}$, and temperature around $300-350^{\circ} \mathrm{C}$. The detailed process unit operations used for the production of methanol from NG are shown in Fig. 1. The highest efficiency reported in the manufacturing of methanol from NG is $66 \%$ (Kajaste et al. 2018). The coal to methanol production route contributes to higher $\mathrm{CO}_{2}$ emissions with low energy efficiency (Xiang et al. 2015).

\section{Ethanol production (96\% concentrated)}

Before 1947, ethanol was produced by indirect hydration of ethene. However, after industrialization, production was routed via direct hydration of ethene as shown in equation 3 (Weissermel \& Arpe 2008, Liu et al. 2019). Ethanol (96\%) production from the hydrogenation of the nitric acid process is shown in Fig. 2.

$$
\mathrm{H}_{2} \mathrm{C}=\mathrm{CH}_{2}+\mathrm{H}_{2} \mathrm{O} \leftrightarrow \mathrm{C}_{2} \mathrm{H}_{5} \mathrm{OH}
$$

The reaction occurs in a gas phase reactor with acid catalysis. The catalyst is nitric acid. The conversion rate is quite low (only 5.6\%), so unreacted ethylene and ether from side reactions are recycled. The raw product is purified by distillation and the addition of sodium hydroxide to remove aldehydes (Falano et al. 2014, Li et al. 2018).

Currently, India produces ethanol from B-heavy molasses and damaged food grains to fulfill the demand for blending. Ethanol production through molasses is a fermentation biological process, in which molasses are converted into cellular energy, ethanol, and carbon dioxide (Soam et al. 2015).

Production data for molasses to ethanol mainly for en- 


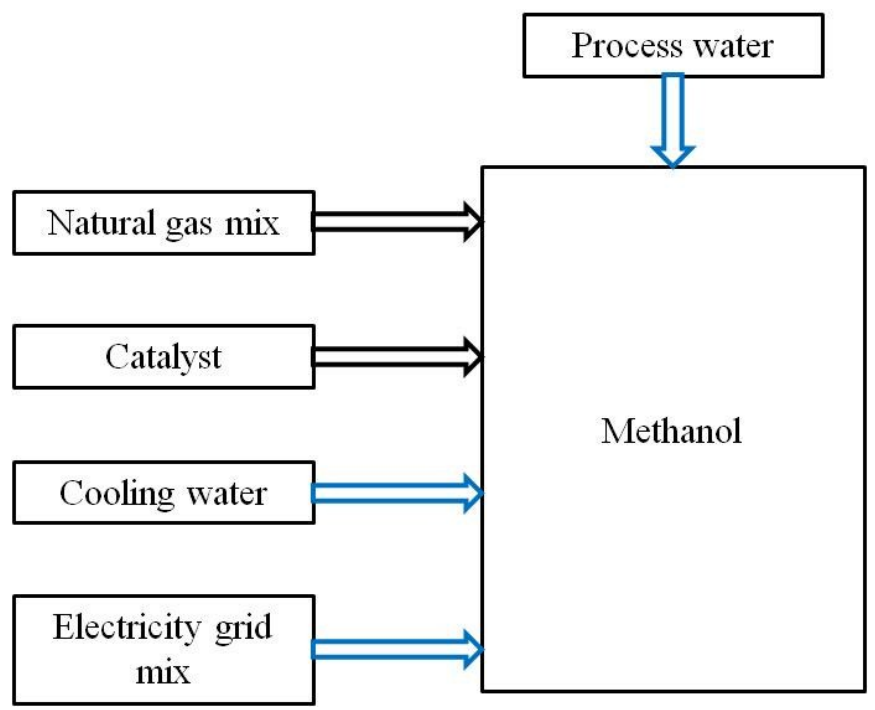

Fig. 1: Methanol production from natural gas.

zyme and yeast were found fluctuating in literature, so we have considered only hydration process production data for further analysis.

\section{n-Butanol Production}

Production of n-butanol can be done by two processes, i.e., petrochemical and biobased. The organic manufacture of butanol was one of the greatest commercial fermentation techniques in the early twentieth century, but it lost popularity in 1960 when researchers developed more cost-effective substrates and more efficient petrochemical processes, such as the oxo-synthesis (Patil et al. 2019). Hydroformylation of propene is also known as an Oxo-synthesis process. Oxo-synthesis process is propene and syngas $\left(\mathrm{CO}+\mathrm{H}_{2}\right)$ in the presence of a catalyst with several reaction conditions (pressure, temperature) used as a feed stream for the production of n-butanol. The detailed reaction is shown in equation 4. Uyttebroek et al. (2015) demonstrated a hydroformylation process using $\mathrm{Rh}$ base catalyst at low pressure, producing 95\% of n-butanol and 5\% 2-methyl-1-propanol (Uyttebroek et al. 2015). A detailed overview of n-butanol production from the Oxo process is shown in Fig. 3.

Production is modeled using the Oxo synthesis process or propylene hydroformylation. This low-pressure liquid-phase

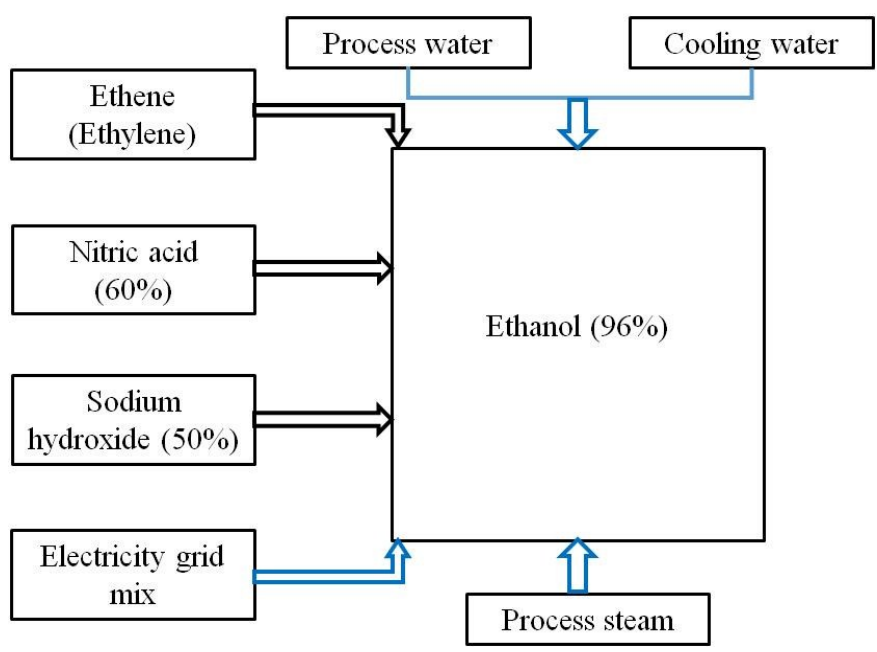

Fig. 2: Ethanol (96\%) production from the hydrogenation of nitric acid. 
process combines liquid-phase propylene and synthesis gas (a 1:1 mixture of hydrogen and carbon monoxide) in the presence of modified Rhodium catalysts to produce aldehydes, which are further hydrogenated to produce butanol isomers. This process is typically optimized for the production of n-butanol, with yields of up to $98 \%$ n-butanol.

$$
\mathrm{R}-\mathrm{CH}=\mathrm{CH}_{2}+\mathrm{CO}+\mathrm{H}_{2} \rightarrow \mathrm{R}-\mathrm{CH}_{2}-\mathrm{CH}_{2} \mathrm{CHO}
$$

The properties of gasoline and alcohol considered in the present study are mentioned in Table 1 .

\section{Life Cycle Assessment (LCA)}

LCA is a tool for systematic analysis of ecological features of products, and unit processes. Its importance has been grown in recent years as it helps to make environmental-based decisions. Detailed LCA framework for gasoline blending production study is shown in Fig. 4.

As per ISO a 14040 norm, LCA is performed in four phases:

1. Goal and scope

2. Inventory analysis

3. Impact assessment

4. Interpretation

\section{Goal and scope}

The goal and scope generally depend on the application, the geographical locations, and the time frame. The goal of the current study is to provide an outline of the cradle-to-gate LCA of different gasoline blending in an Indian context. The LCA included all raw materials and utilities. It excludes the construction, distribution, fugitive emissions, and use phases. In the present study, $1.0 \mathrm{t}$ production of gasoline with different ratios (5-100 wt.\%) of methanol, ethanol, and n-butanol as an additive is considered as a functional unit.

\section{Inventory Analysis}

The inventory describes the product system and its subprocesses by gathering data and calculating allocation. For inventory analysis of the gasoline blend, the mass balance is estimated on a according to per ton basis.. The primary data on the production of the additives is collected from the $\mathrm{GaBi}$ Indian database. For methanol and ethanol, data was directly collected from GaBi. The inventory was created for n-butanol as this was not available in the database.

\section{Impact Assessment}

In impact assessment, the information collected is analyzed for the probable environmental emissions. These impacts are expressed in equivalent units. In this paper, the CML 2001 method is used for emissions category representation.

\section{Interpretation}

In the interpretation phase, the results are analyzed including

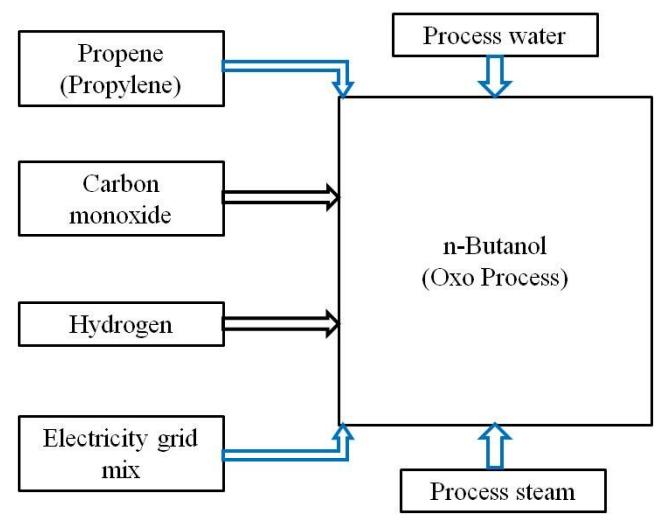

Fig. 3: n-butanol production from oxo process.

Table 1: Properties of gasoline and alcohol.

\begin{tabular}{|llll|}
\hline Properties & Gross calorific value $(\mathrm{MJ} / \mathrm{kg})$ & Net calorific value $(\mathrm{MJ} / \mathrm{kg})$ & Density $(\mathrm{kg} / \mathrm{L})$ \\
\hline Gasoline & 47.1 & 43.9 & 0.732 \\
Methanol & 22.7 & 19.9 & 0.794 \\
Ethanol & 29.7 & 26.8 & 0.809 \\
n-butanol & 36 & 33.1 & 0.813 \\
\hline
\end{tabular}


the relative contribution of individual process steps to the total with the above three phases. The conclusions are drawn depending on the findings of overall and component-based environmental impact.

\section{RESULTS AND DISCUSSION}

In order to convey the information included in the inventory and its significance to the environment, an impact assessment is carried out. The process flow scheme for the gasoline blend with different oxygenates is developed in $\mathrm{GaBi}$. $\mathrm{GaBi}$ Professional software version 8.7 with the Indian Extension Database is used to analyze the environmental impacts.

\section{Global Warming Potential (GWP)}

Global warming is the increase in the warming of the troposphere due to the increase in anthropogenic greenhouse gases (GHG) in the atmosphere. The potential greenhouse effects of these gases are converted in reference to carbon dioxide $\left(\mathrm{CO}_{2}\right)$.

GWP of gasoline blending production with methanol (M), ethanol (E), and n-butanol (B) is shown in Fig. 5. From Fig. 5, it is clearly indicated that with increasing $\%$ of blending from $5 \%$ to $100 \%$, GWP of methanol blended gasoline remains nearly constant. Whereas, GWP of ethanol and n-butanol blended gasoline gradually increases with increasing $\%$ blending. Gasoline blending with ethanol showed the highest GWP followed by n-butanol and methanol. The reason could be that during ethanol production there are major two contributors to GWP, i.e., process steam from natural gas and ethene production. Whereas, in the case of n-butanol gasoline blend, n-butanol itself, propene (Pereira et al. 2015) and hydrogen production are major contributors to GWP as compared to gasoline. In the case of methanol gasoline blending, the primary pollution is because of natural gas production only (Lemonidou et al. 2003).

Most of the researchers reported GWP for methanol blended gasoline: $0.462 \mathrm{~kg} \mathrm{CO}$ eq. $\mathrm{kg}^{-1} \mathrm{CH}_{3} \mathrm{OH}$ and which is lower than the present study i.e. $0.832 \mathrm{~kg} \mathrm{CO}_{2}$ eq. $\mathrm{kg}^{-1}$ $\mathrm{CH}_{3} \mathrm{OH}$ (Yadav et al. 2020). Whereas, for ethanol-blended gasoline, GWP was found to be $2.22 \mathrm{~kg} \mathrm{CO}_{2}$ eq. $\mathrm{kg}^{-1} \mathrm{~g} \mathrm{C}_{2} \mathrm{H}_{5} \mathrm{OH}$, which is quite higher as compared to cradle-to-gate in Western Europe i.e. $1.3 \mathrm{~kg} \mathrm{CO}_{2}$ eq. $\mathrm{kg}^{-1}$ (Muñoz et al. 2014). The higher values of GWP found in the present study for ethanol-blended gasoline may be due to the electricity generation from coal, transportation, and also the reporting method used (ReciPe). Individually, gasoline production has the lowest GWP $(13.52 \mathrm{~g}$ $\mathrm{CO}_{2}$ eq. $\mathrm{MJ}^{-1}$ ) among methanol, ethanol, and n-butanol which is in the range of most results ( 10 and $15 \mathrm{~g} \mathrm{CO}_{2}$ eq. $\mathrm{MJ}^{-1}$ fuel) (Eriksson \& Ahlgren 2013). Alcohol production from biomass particularly minimizes GHGs creation and result in global warming (Dalena et al. 2018).

\section{Acidification Potential (AP)}

Acidification potential is an increase in the acidity of the earth, a waterbody, or atmosphere due to human activities.

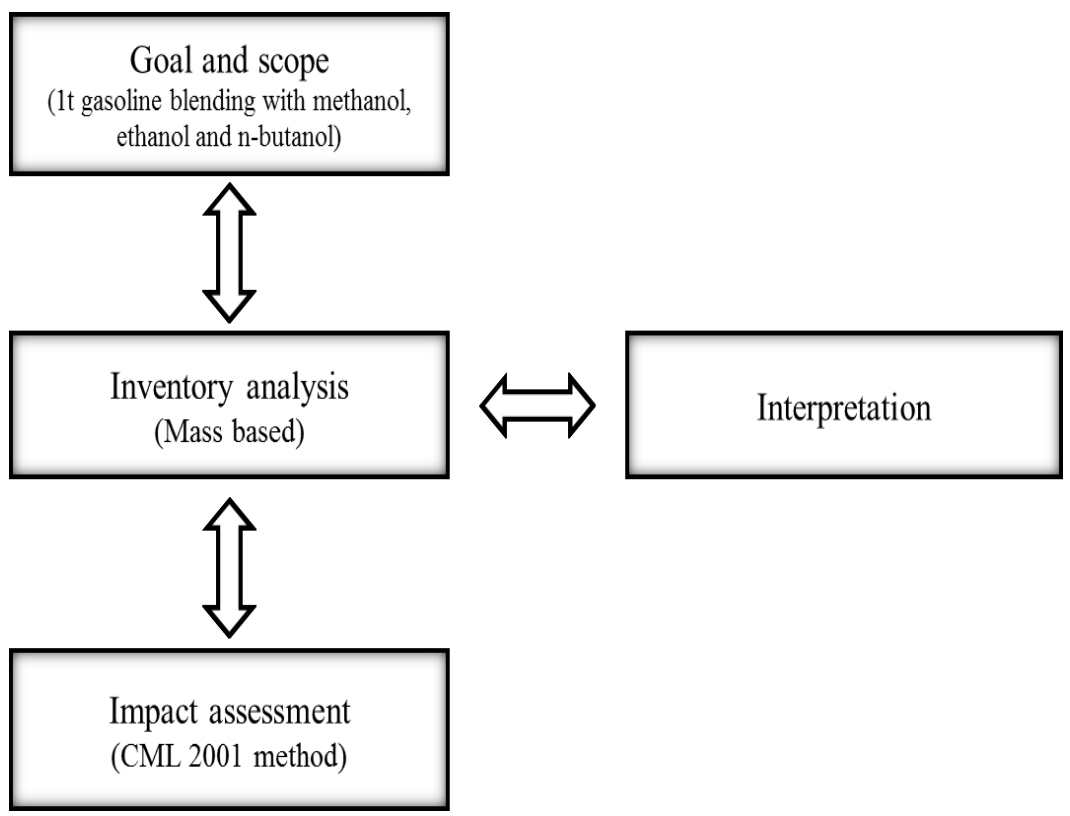

Fig. 4: LCA framework for gasoline blending production study. 
The increase in the acidity of the air leads to an increase in the $\mathrm{pH}$ value.

The detailed AP from the production of gasoline blending with methanol, ethanol, and n-butanol is shown in Fig. 6. AP of methanol and ethanol-blended gasoline increases with increasing blending $\%$ from $5 \%$ to $15 \%$ whereas, decreases from $50 \%$ and onwards. The reason could be, independently gasoline production has the second most AP $(6.3 \mathrm{E}-03 \mathrm{~kg}$ $\mathrm{SO}_{2}$ eq. $\mathrm{kg}^{-1}$ ). In the case of $\mathrm{n}$-butanol blended gasoline, the authors found an almost constant AP irrespective of \% blending. The higher values of AP in the case of n-butanol (7.88E-03 $\mathrm{kg} \mathrm{SO}_{2}$ eq. $\mathrm{kg}^{-1}$ ) are on account of electricity and process steam generation. However, it was reported that n-butanol production from the petrochemical route had lower AP than bio-butanol due to the use of fertilizer during the agricultural stage (Pereira et al. 2015).

\section{Eutrophication Potential (EP)}

The EP is the excessive addition of nutrients such as nitrogen and phosphorus liberated into water and land. Phosphorus and nitrogen from agriculture, combustion processes, and industry effluents mainly cause eutrophication. Emissions of pollutants are converted into $\mathrm{kg} \mathrm{PO}_{4}$ - eq. EP of methanol, ethanol, and n-butanol blended gasoline comparative results are shown in Fig. 7. As the percentage of methanol blending increases from $5 \%$ to $15 \%$, EP showed higher values whereas, with an increase in methanol blending from $50 \%$ to $100 \%$, EP decreases. However, for ethanol blending with gasoline, it is nearly constant. Discrete production comparison shows gasoline has the second most EP $(0.418 \mathrm{E}-3 \mathrm{~kg}$
Phosphate eq. $\mathrm{kg}^{-1}$ ). EP of gasoline blended with n-butanol contributes 28 times higher followed by gasoline. The EP of alcohol blended gasoline from discrete production potential is lowest compared with methanol $\left(0.16 \mathrm{E}-3 \mathrm{~kg} \mathrm{PO} 4^{-}\right.$eq. $\left.\mathrm{kg}^{-1}\right)$ ethanol, and n-butanol. The highest $\mathrm{EP}\left(0.53 \mathrm{~kg} \mathrm{PO}_{4}\right.$ - eq. $\left.\mathrm{kg}^{-1}\right)$ in the case of n-butanol may be contributed because of the electricity, process, steam generation, propene, and carbon monoxide. Pereira et al. (2015) reported that petrochemical n-butanol has lower EP compared to biobutanol. However, in the case of ethanol blending, it is due to process steam production only. Falano et al. (2014) also calculated EP for ethanol ( $\mathrm{PO}_{4^{-}}$eq.) as $1.17 \mathrm{gm} . \mathrm{L}^{-1}$ which is nearly equal to $0.91 \mathrm{gm} . \mathrm{L}^{-1}$ calculated in the present study.

\section{Ozone Depletion Potential (ODP)}

This impact highlights the deterioration of the ozone layer of the stratosphere which protects living beings from ultraviolet rays. Halocarbons like chloro-fluoro-carbons or synthetic halogenated compounds prevent stratospheric ozone creation and thus limit the regeneration of the ozone layer.

ODP with respect to methanol, ethanol, and n-butanol blended gasoline is shown in Fig. 8. It was observed that with an increase in alcohol blending \% in gasoline, the ODP also increases in the case of ethanol and n-butanol except for methanol. Methanol blended gasoline production does not show much effect even though it increases from 5\% to $100 \%$. ODP is maximum for the gasoline blending with ethanol followed by n-butanol mostly in case of higher blending from $50 \%, 85 \%$, and $100 \%$. Principally, ethene $\left(\mathrm{CH}_{2}=\mathrm{CH}_{2}\right)$, water $\left(\mathrm{H}_{2} \mathrm{O}\right)$ and sodium hydroxide $(\mathrm{NaOH})$ production are the

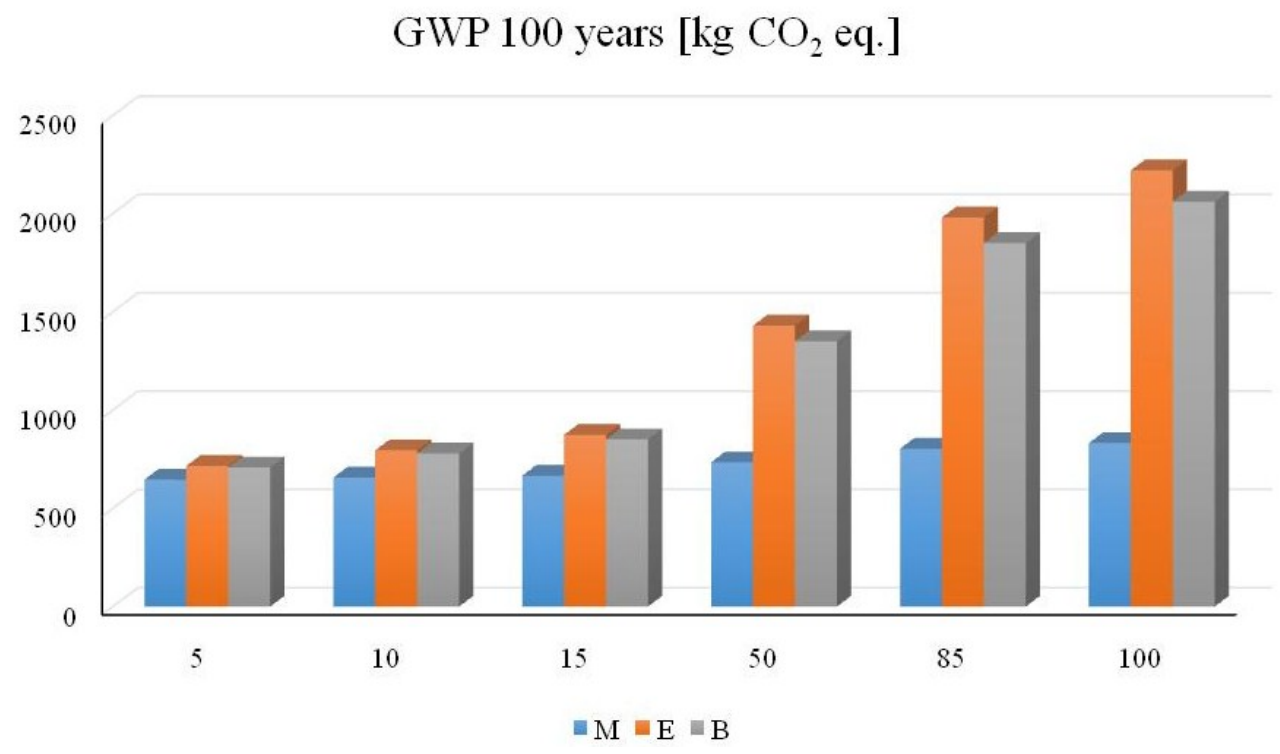

Fig. 5: GWP of gasoline blending production with methanol (M), ethanol (E) and n-butanol (B). 
primary contributors that damage ozone. ODP for gasoline blending with n-butanol is mainly contributed by propene and electricity generation of n-butanol. Similar results were disclosed by Pereira et al. (2015), in the case of petrochemical route n-butanol production. The authors mentioned that the use of propylene and heat from natural resources during the production stage were major contributors. Independent production observed the lowest ODP for gasoline (8.19E-15 $\mathrm{kg}$ R11 eq.kg-1).

\section{Abiotic Depletion Potential (ADP) for Elements and Fossil}

The impact category was subdivided into two categories, using two sets of ADPs: the ADP for elements and the ADP for fossil fuels. Fig. 9 (a) and (b) shows ADP (element) and ADP (fossils), respectively, for gasoline blending with methanol, ethanol, and n-butanol. ADP element for gasoline blending with n-butanol is mainly due to propene production. It is also seen that gasoline production has the lowest

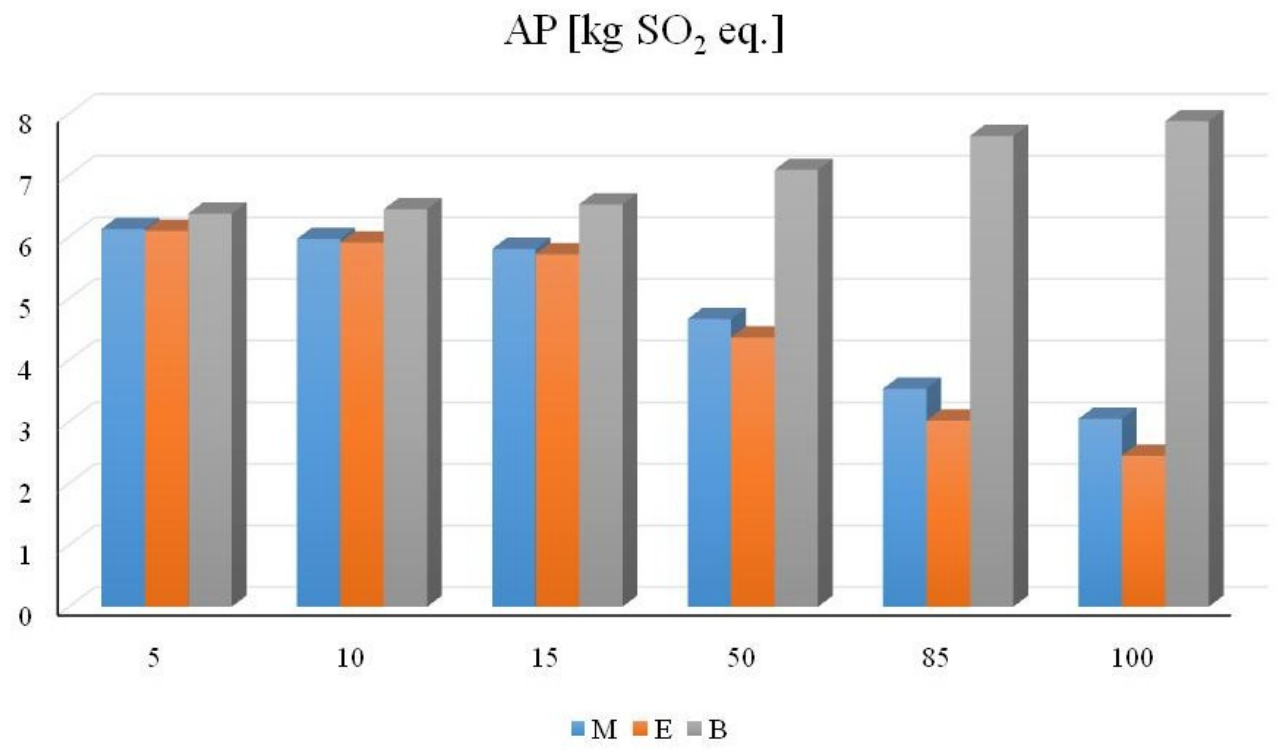

Fig. 6: AP of gasoline blending production with methanol (M), ethanol (E), and n-butanol (B).

\section{EP [kg Phosphate eq.]}

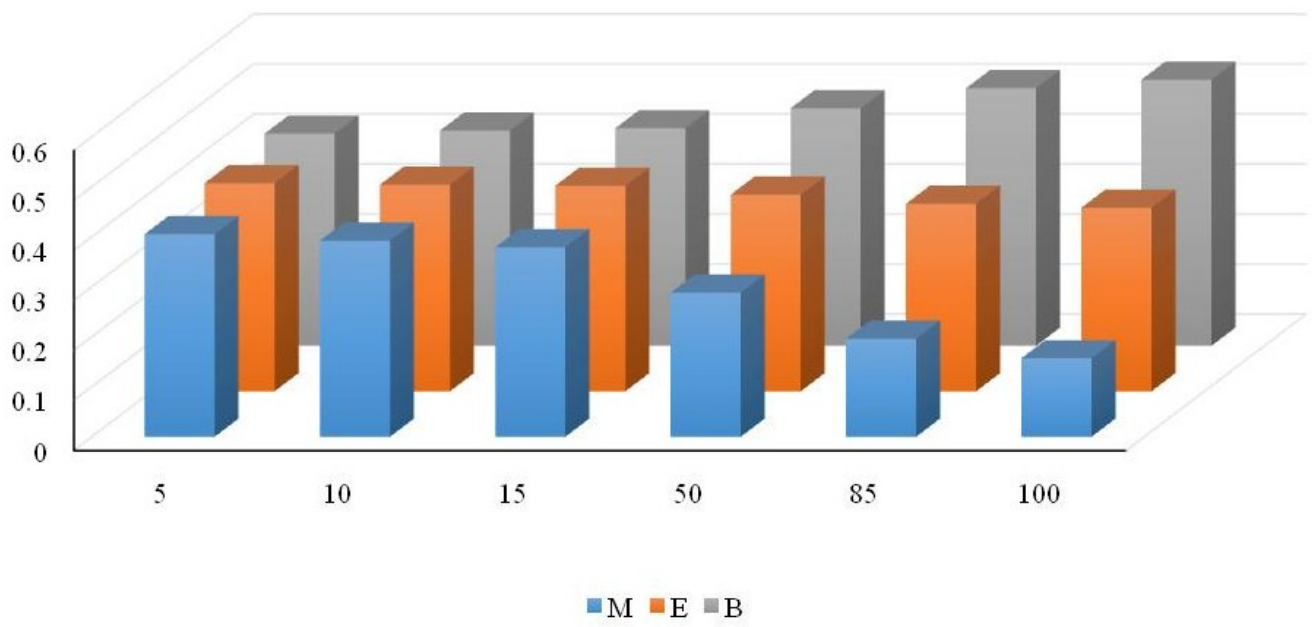

Fig. 7: EP of gasoline blending production with methanol (M), ethanol (E) and n-butanol (B). 
ADP elements. ADP (element) is the highest for gasoline blending with ethanol followed by methanol. As \% blending of alcohol increases, ADP also increases. Initial 5\% to $15 \%$ alcohol blended gasoline showed the lowest ADP and increased afterward with increasing alcohol blending $\%$. This is mainly on account of ethane and sodium hydroxide production (Li et al. 2018).

ADP fossil impact for alcohol gasoline blending is nearly constant up to $15 \%$. Ethene and process steam from natural gas are major contributors to ethanol ADP (fossil) impact. ADP (fossil) for gasoline blending with n-butanol is mainly contributed by propene and hydrogen production of n-butanol and the equal contribution by gasoline. It is also observed that individually, gasoline production has the third most (49.1 MJ. $\mathrm{kg}^{-1}$ ) ADP fossils. In the present study (India), ADP (fossil) is calculated around 36.4 GJ.t. $\mathrm{t}^{-1}$ methanol which is coherent with the $33.4 \mathrm{GJ}^{-\mathrm{t}^{-1}}$ methanol reported by Li et al. 2018.

\section{Human Toxicity Potential (HTP)}

HTP is a continuous toxicological impact on humans. The effect of percentage gasoline blending with methanol, ethanol, and n-butanol is shown in Fig. 10. For gasoline blending with n-butanol, n-butanol contributes $73 \%$ higher than gasoline. Process steam generation mainly contributes to n-butanol followed by propene and electricity generation. However, Pereira et al. (2015) reported that petrochemical n-butanol production had similar HTP compared with biobutanol.
Individually, gasoline production has the second most HTP. It is interesting to observe that the methanol addition helps to reduce the HTP impact. Khoo et al. (2016) also found (HTP) $0.4 \mathrm{~kg}$ DCB eq... $\mathrm{kg}^{-1} \mathrm{CH}_{3} \mathrm{OH}$ which is higher than $0.075 \mathrm{~kg}$ DCB eq.. $\mathrm{kg}^{-1} \mathrm{CH}_{3} \mathrm{OH}$ calculated in the current study. Falano et al. (2014) calculated HTP (DCB eq.) for ethanol as 142 $\mathrm{gm} . \mathrm{L}^{-1}$ and in the present study, it is around $192 \mathrm{gm} . \mathrm{L}^{-1}$. The difference in the impact values may be due to the different sources of electricity generation, fuel composition, and also the reporting method used.

\section{Terrrestric (TETP), Marine Aquatic Ecotoxicity Potential (MAETP), and Photochemical Ozone Creation Potential (POCP)}

TETP, MAETP, and POCP are the highest for gasoline blending with n-butanol as shown in Fig. 11, 12, and 13, respectively. TETP for gasoline blending with n-butanol, gasoline, and n-butanol contribute nearly in equal proportions, i.e., 1.6E-3 and $1.8 \mathrm{E}-3 \mathrm{~kg} \mathrm{DCB}$ eq. $\mathrm{kg}^{-1}$ respectively. Process steam and electricity generation contribute to n-butanol TETP impact. Similarly, electricity generation is also the main contributor to methanol production.

MAETP for gasoline blending with n-butanol, n-butanol contributes 5.6 times higher than gasoline. Process steam and electricity generation mainly add to this impact.

POCP impact is related to ozone creation and it is expressed in the amount of ethene equivalent emitted. Khoo et al. (2016) reported POCP $1.25 \mathrm{E}-4 \mathrm{~kg}$ ethene eq. $\mathrm{kg}^{-1} \mathrm{CH}_{3} \mathrm{OH}$,

\section{ODP [kg R11 eq. $]$}

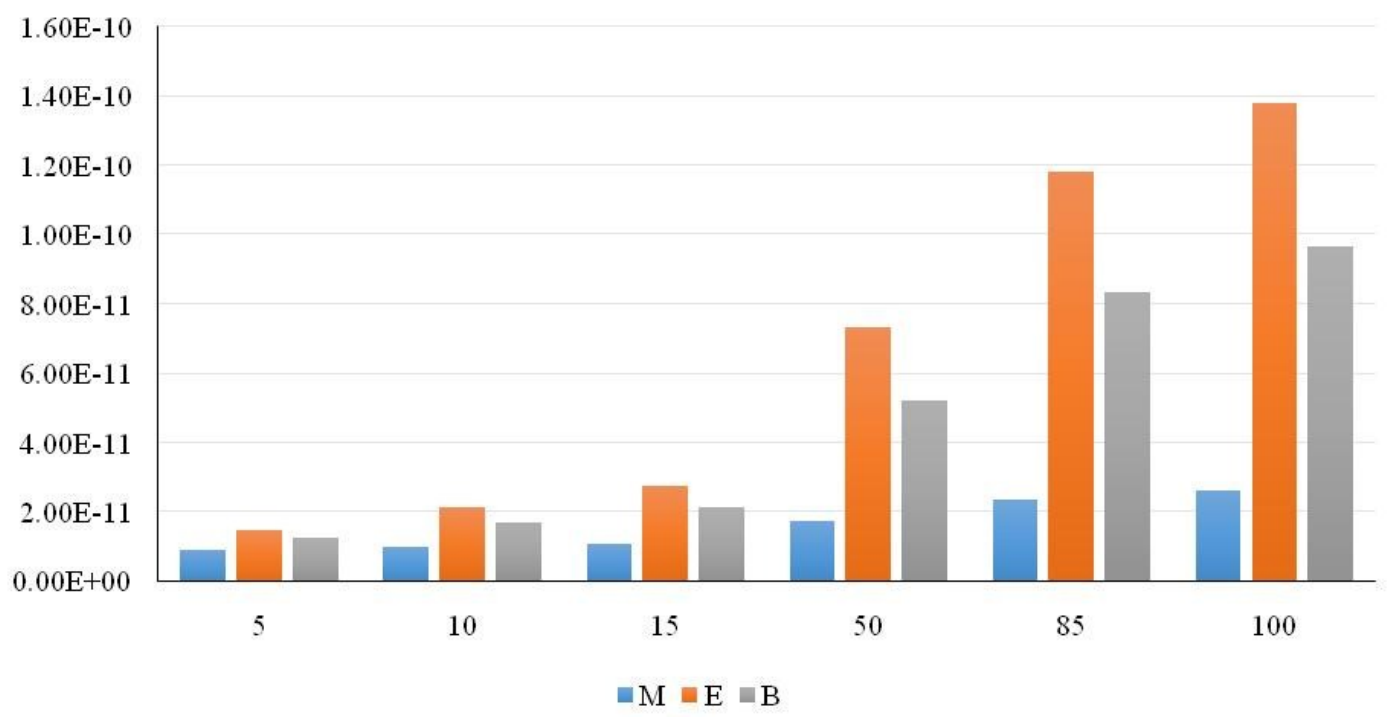

Fig. 8: ODP of gasoline blending production with methanol (M), ethanol (E), and n-butanol (B). 
which is lower than 3.1E-4 kg ethene eq. $\mathrm{kg}^{-1} \mathrm{CH}_{3} \mathrm{OH}$ calculated in the current study. POCP for gasoline blending with n-butanol is mainly contributed by gasoline $(6.48 \mathrm{E}-4 \mathrm{~kg}$ ethene eq. $\mathrm{kg}^{-1}$ ) followed by n-butanol (5.57E-4 kg ethene eq. $\left.\mathrm{kg}^{-1}\right)$. POCP of gasoline is added due to volatile organic compound emissions in transport and distribution (Furuholt 1995). In n-butanol, propene and hydrogen production contribute to the impacts compared to biobutanol (Pereira et al. 2015).

\section{CONCLUSION}

A detailed investigation of the environmental impact and implications of blending gasoline with (varying percents) methanol, ethanol, and n-butanol for the first time in India is presented in this paper on LCA methodology. The alcohol production through the chemical route, i.e., methanol from natural gas reforming process, ethanol from hydrogenation with nitric acid, and n-butanol from oxo process are considered.

\section{$\mathrm{ADP}$ elements [kg Sb eq.]}

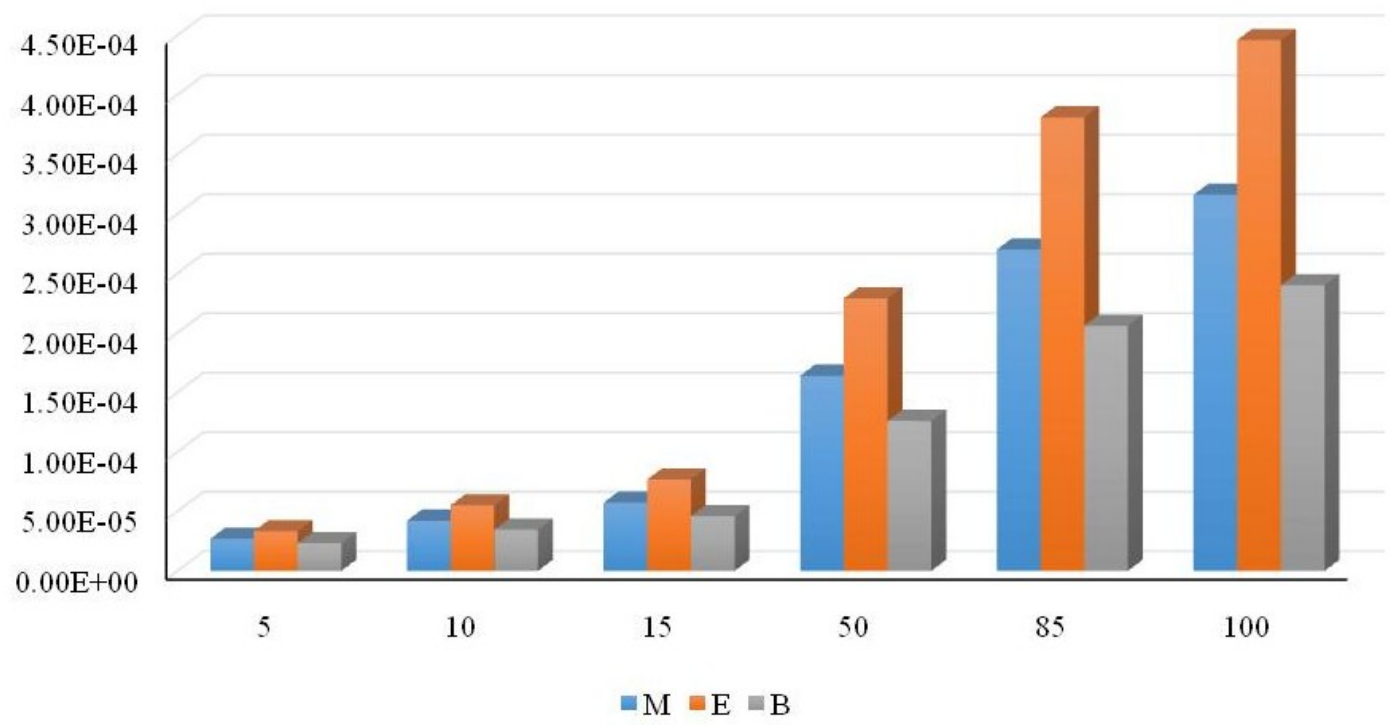

Fig. 9 (a): ADP (elements) of gasoline blending production with methanol (M), ethanol (E), and n-butanol (B).

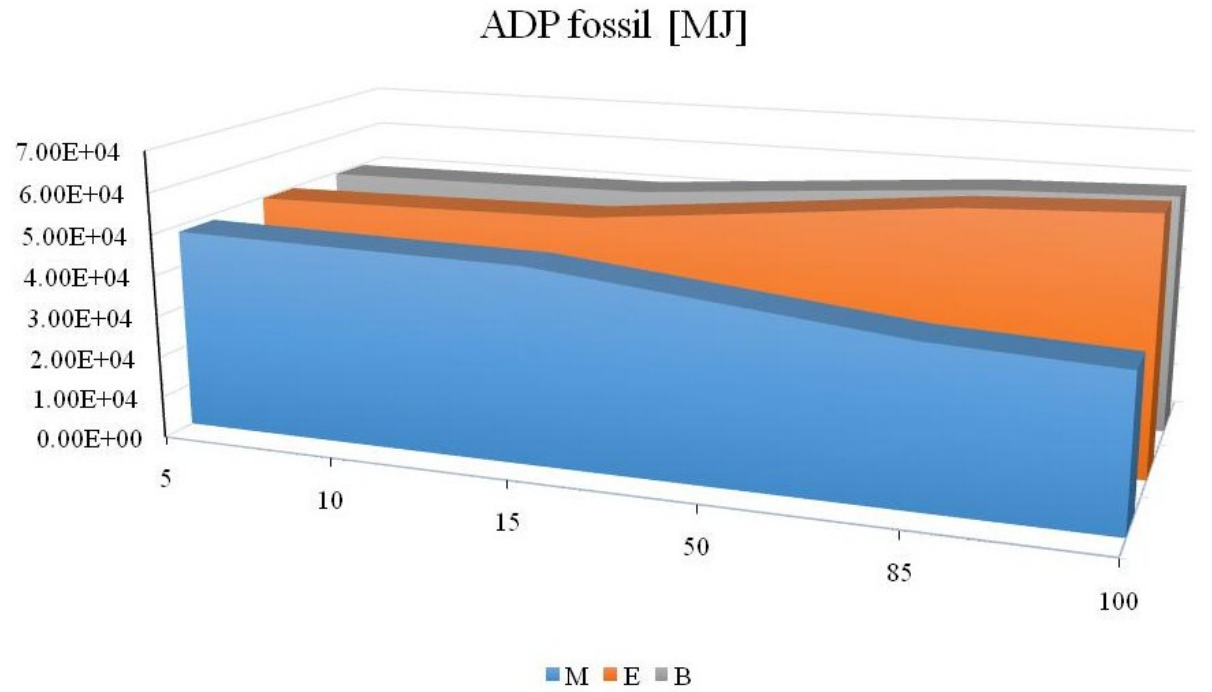

Fig. 9 (b): ADP (fossil) of gasoline blending production with methanol (M), ethanol (E), and n-butanol (B). 
The results show that the gasoline blending with methanol has the lowest impact and is nearly constant from 5 to $15 \%$. For gasoline with ethanol as an additive, the GWP, ODP, and ADP rise with increasing ethanol addition. Meanwhile, increasing ethanol addition reduces the AP and TETP impact of gasoline. Similarly, n-butanol has higher environmental impacts such as AP, EP, HTP, TETP, MAETP, and POCP compared to methanol and ethanol. Gasoline production has the second-most AP, EP, HTP, and TETP impact. Thus, out of 11,6 of the environmental impact categories of n-butanol as an additive were consistently higher than that of methanol and ethanol.
It is not possible to state which alcohol or which route (petrochemical or biomass) is environmentally friendly overall. Blending during the production, use, and end-of-life cycle in India must be examined economically, environmentally, and sustainably. Gasoline blending appears to be more sustainable only when the additives are produced through the biological route for cleaner energy. However, the overall efficiency, energy use, and economic evaluation can play a deciding role.

\section{DISCLAIMER}

The results are based on information and data from the $\mathrm{GaBi}$ Indian database.

\section{HTP inf. [kg DCB eq.]}

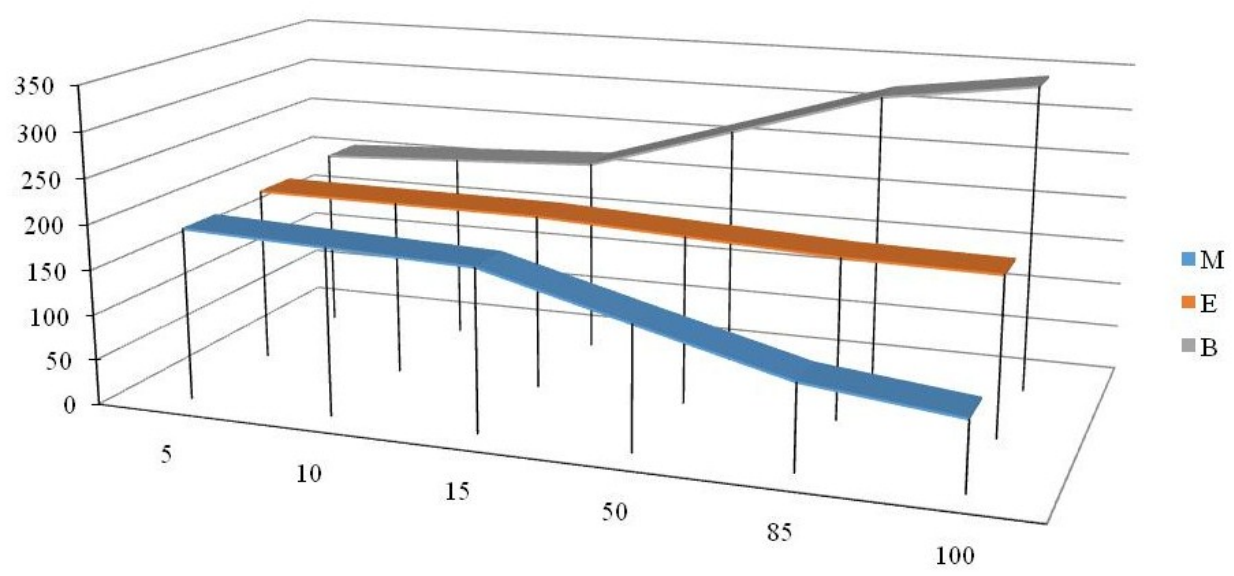

Fig. 10: HTP of gasoline blending production with methanol (M), ethanol (E), and n-butanol (B).

\section{TETP inf. [kg DCB eq.]}

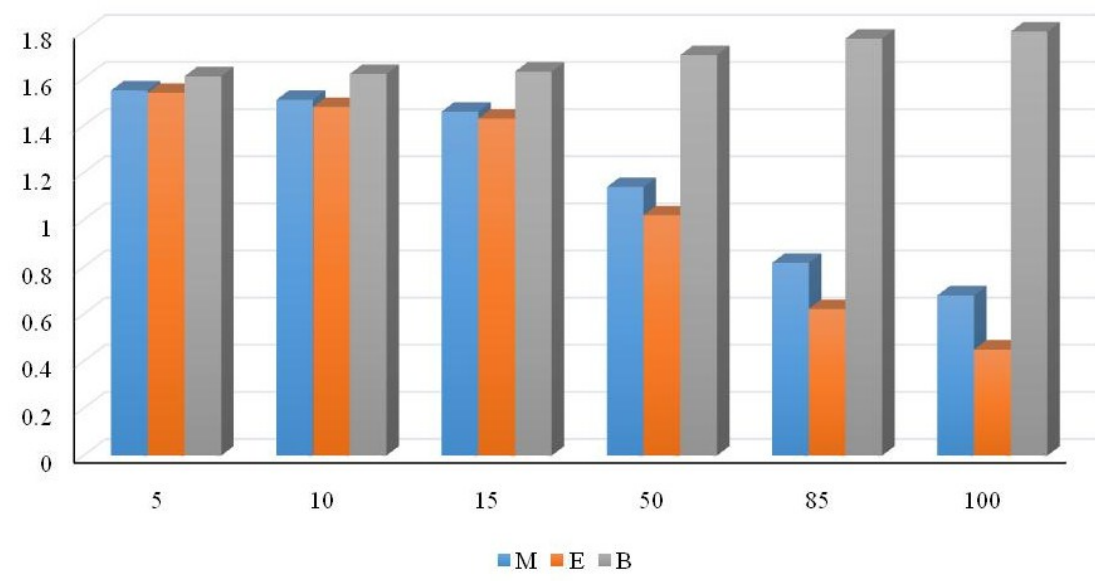

Fig. 11: TETP of gasoline blending production with methanol (M), ethanol (E), and n-butanol (B). 


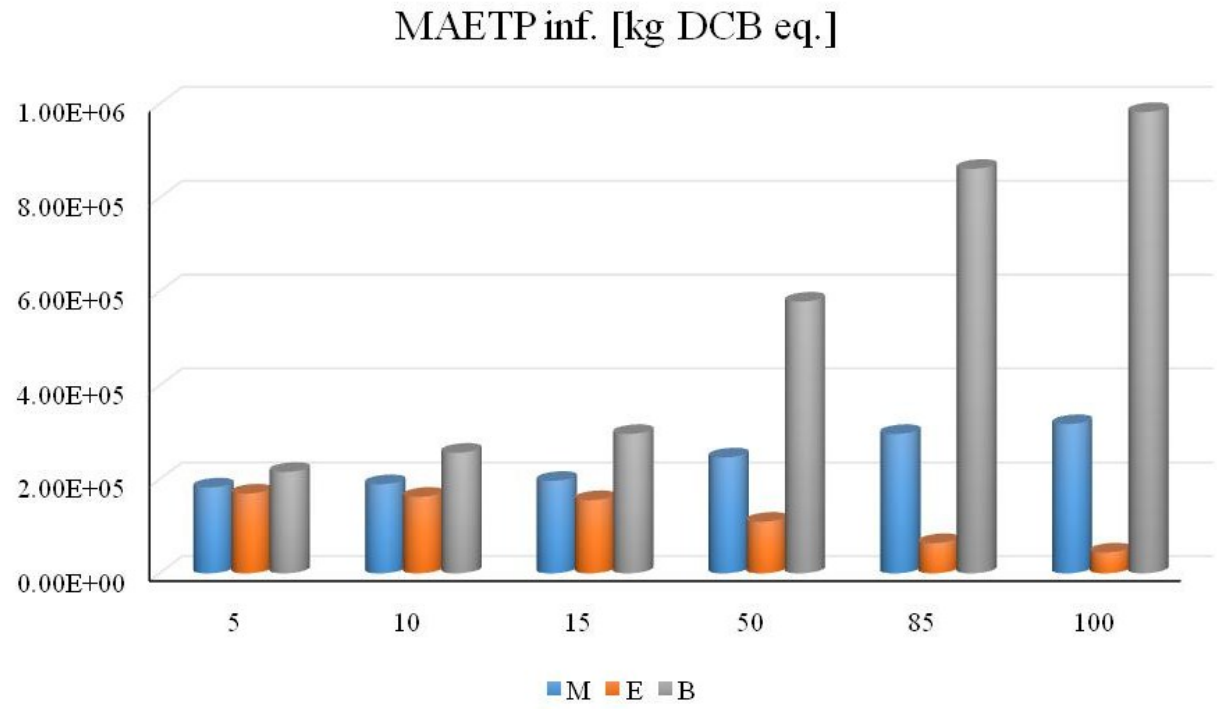

Fig. 12: MAETP of gasoline blending production with methanol (M), ethanol (E), and n-butanol (B).

\section{POCP [kg Ethene eq.]}

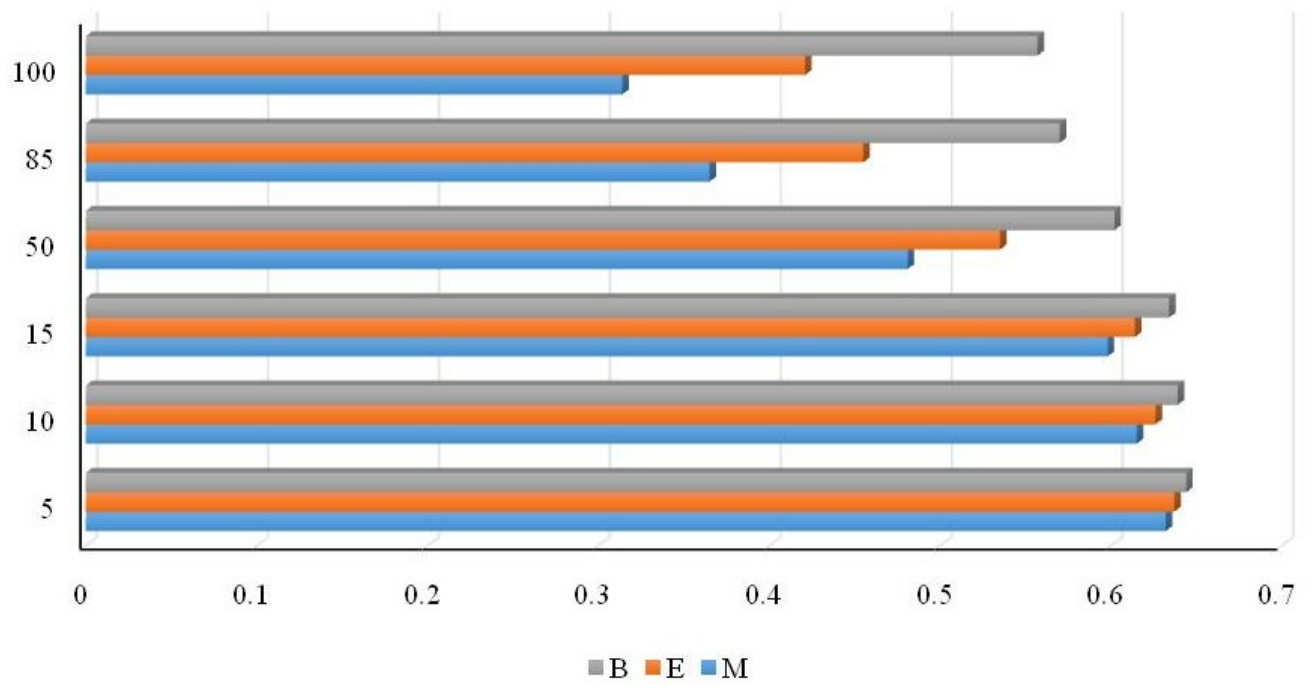

Fig. 13: POCP of gasoline blending production with methanol (M), ethanol (E), and n-butanol (B).

\section{ABBREVIATIONS}

ADP - Abiotic depletion potential

AP - Acidification potential

DCB - Di-chloro Benzene

EP - Eutrophication potential

GHG - Greenhouse gas

GWP - Global warming potential
HTP - Human toxicity potential

LCA - Life cycle assessment

MAETP - Marine aquatic ecotoxicity potential

NG - Natural gas

ODP - Ozone depletion potential

POCP - Photochemical ozone creation potential

TETP - Terrestric ecotoxicity potential 


\section{REFERENCES}

Canakci, M., Ozsezen, A.N., Alptekin, E. and Eyidogan, M. 2013. Impact of methanol-gasoline fuel blends on the exhaust emission of an SI engine. Renew. Energy, 52: 111-117.

Chen, Y., Ma, J., Han, B., Zhang, P., Hua, H., Chen, H. and Su, X. 2018. Emissions of automobiles fueled with alternative fuels based on engine technology: A review. J. Traffic Transp. Eng. Engl. Ed., 5(4): 318-334.

Dalena, F., Senatore, A., Basile, M., Knani, S., Basile, A. and Iulianelli, A. 2018. Advances in methanol production and utilization, with a particular emphasis toward hydrogen generation via membrane reactor technology. Membranes, 8(4): 98.

Eriksson, M. and Ahlgren, S. 2013. LCAs of petrol and diesel: A literature review. Report, 2013: 058.

Falano, T., Jeswani, H.K. and Azapagic, A. 2014. Assessing the environmental sustainability of ethanol from integrated biorefineries. Biotechnol. J., 9(6): 753-765.

Furuholt, E. 1995. Life cycle assessment of gasoline and diesel. Resour. Conserv. Recy., 14(3-4): 251-263.

Heo, J.N., Son, N., Shin, J., Do, J.Y. and Kang, M. 2020. Efficient hydrogen production by low-temperature steam reforming of propane using catalysts with very small amounts of $\mathrm{Pt}$ loaded on $\mathrm{NiMn}_{2} \mathrm{O}_{4}$ particles. Int. J. Hydrog. Energy, 45(41) : 20904-20921.

Hu, X., Yang, J., Sun, W., Wang, N., An, S., Wang, Q., Zhang, Y., Xie, X. and Huang, L. 2020. The Y-Zr-O solid solution supported Ni-based catalysts for hydrogen production via auto-thermal reforming of acetic acid. Appl. Catal. B-Environ., 278: 119264.

Kajaste, R., Hurme, M. and Oinas, P. 2018. Methanol-managing greenhouse gas emissions in the production chain by optimizing the resource base. AIMS Energy, 6(6): 1074-1102.

Karaosmanoglu, F., Isigigur-Ergudenler, A. and Aksoy, H.A. 2000. A new blending agent and its effects on methanol-gasoline fuels. Energy Sources, 22(3): 235-245.

Khoo, H.H., Ee, W.L. and Isoni, V. 2016. Bio-chemicals from lignocellulose feedstock: sustainability, LCA and the green conundrum. Green Chem., 18 (7): 1912-1922.

Lemonidou, A.A., Valla, J. and Vasalos, I.A. 2003. Methanol Production from Natural Gas. In: Aresta M. (eds), Carbon Dioxide Recovery and Utilization. Springer, Dordrecht, pp. 379-394.

Li, J., Ma, X., Liu, H. and Zhang, X. 2018. Life cycle assessment and economic analysis of methanol production from coke gas compared with coal and natural gas routes. J. Clean. Prod., 185: 299-308.

Liu, C., Li, K., Wen, Y., Geng, B., Liu, Q. and Lin, Y. 2019. Bioethanol: New opportunities for an ancient product. Adv. Bioenergy, 4: 1-34.

Ma, R., Xu, B. and Zhang, X. 2019. Catalytic partial oxidation (CPOX) of natural gas and renewable hydrocarbons/oxygenated hydrocarbons- $\mathrm{A}$ review. Catal. Today, 338: 18-30.

Mata, T.M., Smith, R.L., Young, D.M. and Costa, C.A.V. 2003. Life cycle assessment of gasoline blending options. Environ. Sci. Technol., 37(16): 3724-3732.

Muñoz, I., Flury, K., Jungbluth, N., Rigarlsford, G., Canals, L. and King, H. 2014. Life cycle assessment of bio-based ethanol produced from different agricultural feedstocks. Int. J. Life Cycle Assess., 19: 109-119.
Ndaba, B., Chiyanzu, I. and Marx, S. 2015. n-Butanol derived from biochemical and chemical routes: A review. Biotechnol. Rep., 8: 1-9.

Patil, R.C., Suryawanshi, P.G., Kataki, R. and Goud, V.V. 2019. Chapter 8 - Current Challenges and Advances in Butanol Production. Sustainable Bioenergy- Advances and Impact, 225-256.

Pereira, L.G., Chagas, M.F., Dias, M., Cavalett, O. and Bonomi, A. 2015. Life cycle assessment of butanol production in sugarcane biorefineries in Brazil. J. Clean. Prod., 96: 557-568.

Popuri, S.S. and Bata, R.M. 1993. A performance study of iso-butanol-, methanol-, and ethanol-gasoline blends using a single-cylinder engine. SAE Tech. Paper, 932953: 1-22.

Ramalingam, S., Rajendiran, B. and Subramiyan, S. 2020. Recent advances in the performance of co-current gasification technology: A review. Int. J. Hydrog. Energy, 45(1): 230-262.

Saraswat, V.K. and Bansal, R. 2017. India's Leapfrog to Methanol Economy. NITI Aayog, Government of India. Delhi, India, pp. 1-11.

Sheehy, P., Law, K. and Jackson, M.D. 2010. Methanol Fuel Blending and Materials Compatibility Report: Overview of TIAX Report on U.S. Marketplace. The Methanol Institute, Rev A, TIAX Case No. D5607, Arlington, VA, pp. 1-40.

Shirvani, S., Shirvani, S., Shamekhi, A.H. and Reitz, R.D. 2020. A study of using E10 and E85 under direct dual fuel stratification (DDFS) strategy: Exploring the effects of the reactivity-stratification and diffusion-limited injection on emissions and performance in an E10/diesel DDFS engine. Fuel, 275: 117870.

Soam, S., Kumar, R., Gupta, R.P., Sharma, P.K., Tuli, D.K. and Das, B. 2015. Life cycle assessment of fuel ethanol from sugarcane molasses in northern and western India and its impact on Indian biofuel program. Energy, 83: 307-315.

Surisetty, V.R., Dalai, A.K. and Kozinski, J. 2011. Alcohols as alternative fuels: An overview. Appl. Catal. A-Gen., 404(1-2): 1-11.

Uyttebroek, M., Hecke, W.V. and Vanbroekhoven, K. 2015. Sustainability metrics of 1-butanol. Catal. Today, 239: 7-10.

Weissermel, K. and Arpe, H.J. 2008. Industrial Organic Chemistry (Google eBook). John Wiley \& Sons, New York.

Xiang, D., Yang, S., Mai, Z. and Qian, Y. 2015. Comparative study of coal, natural gas, and coke oven gas blend methanol to olefins processes in China. Comput. Chem. Eng., 83: 176-185.

Yadav, P., Athanassiadis, D., Yacout, D., Tysklind, M. and Upadhyayula, V. 2020. Environmental impact and environmental cost assessment of methanol production from wood biomass. Environ. Pollut. Part-A, 265: 114990 .

Yanju, W., Shenghua, L., Hongsong, L., Rui, Y., Jie, L. and Ying, W. 2008. Effects of methanol/gasoline blends on spark-ignition engine performance and emissions. Energy Fuels, 22(2): 1254-1259.

Yuen, P.K., Beckett, J., Villaire and W. 2010. Automotive materials engineering challenges and solutions for the use of ethanol and methanol blended fuels. SAE Tech. Paper, 2010: 729.

Yusri, I.M. , Mamat, R., Najafi, G., Razman, A., Awad, O.I., Azmi, W.H., Ishak, W.F.W. and Shaiful, A.I.M. 2017. Alcohol-based automotive fuels from first four alcohol family in compression and spark ignition engine: A review on engine performance and exhaust emissions. Renew. Sustain. Energ. Rev., 77: 169-181. 